\title{
About the Acidity-Catalytic Activity Relationship in lonic Liquids: Application to the Selective Isobutene Dimerization
}

\author{
L. Magna' ', J. Bildé' , H. Olivier-Bourbigou' ', T. Robert ${ }^{2}$ and B. Gilbert ${ }^{2}$ \\ 1 Institut français du pétrole, IFP-Lyon, Rond-point de l'échangeur de Solaize, BP 3, 69360 Solaize - France \\ 2 Laboratoire de Chimie Analytique, Université de Liège, 4000 Liège - Belgique \\ e-mail: lionel.magna@iff.fr - jean.bilde@iff.fr - helene.olivier-bourbigou@ifp.fr - thierry.rober@ulg.ac.be - b.gilbert@ulg.ac.be
}

\begin{abstract}
Résumé - Acidité et activité catalytique dans les liquides ioniques : application à la dimérisation sélective de l'isobutène - Le niveau d'acidité de Brønsted de différents acides a été évalué dans une série de liquides ioniques non chloroaluminates. Dans une première approche, nous avons utilisé la méthode basée sur la détermination de la fonction de Hammett $\mathrm{H}_{0}$ par la spectroscopie UV-Visible. L'acidité du proton est principalement déterminée par son état de solvatation et sa concentration. Les propriétés des protons dépendent par conséquent à la fois de la nature du solvant et de la nature de l'acide ajouté, ainsi que de sa concentration dans le milieu ionique. Une échelle d'acidité apparente a ainsi été définie. Il ressort, pour la série de liquides ioniques étudiée, que le cation ne joue pas de rôle majeur sur le niveau d'acidité $\left([\mathrm{BMIm}] \sim[\mathrm{BHIm}] \sim\left[\mathrm{HNEt}_{3}\right]\right)$, contrairement à la nature de l'anion du liquide ionique qui conduit à des variations importantes du niveau d'acidité : $\left[\mathrm{SbF}_{6}\right]>\left[\mathrm{PF}_{6}\right]>\left[\mathrm{BF}_{4}\right]>\left[\mathrm{NTf}_{2}\right]>[\mathrm{OTf}]$. Cette échelle d'acidité a été comparée à une échelle d'activité pour la réaction de dimérisation de l'isobutène en isooctènes. Les tendances concernant l'effet du cation sont confirmées par les niveaux de conversion observés en catalyse $\left([\mathrm{BMIm}] \sim[\mathrm{BuMePyrr}] \sim\left[\mathrm{HNEt}_{3}\right]\right)$. On notera cependant un certain décalage en ce qui concerne l'effet de l'anion avec un positionnement différent des liquides ioniques basés sur les anions $\mathrm{NTf}_{2}:\left[\mathrm{NTf}_{2}\right] \sim\left[\mathrm{SbF}_{6}\right]>\left[\mathrm{PF}_{6}\right] \sim\left[\mathrm{BF}_{4}\right]>[\mathrm{OTf}]$. Finalement, sur un plan appliqué, un choix adéquat du liquide ionique et de l'acide ajouté permet d'atteindre, à température ambiante, une sélectivité en isooctènes de $88 \%$ (à $70 \%$ de conversion de l'isobutène) avec un recyclage possible du système catalytique sans perte notable d'activité ni de sélectivité.
\end{abstract}

Abstract - About the Acidity-Catalytic Activity Relationship in Ionic Liquids: Application to the Selective Isobutene Dimerization - The Bronsted acidity level was evaluated for ionic liquids to which a strong acid has been added. As a first approach, the evaluation method was based on the determination of the Hammett acidity functions $H_{0}$, using UV-Visible spectroscopy. The acidity of protons is mainly determined by their solvation state and consequently, the properties of protons depend on both the nature of the solvent and the nature and concentration of the acid. An apparent acidity scale was defined following this principle. It was found that, for the investigated ionic liquids, the cation does not play a

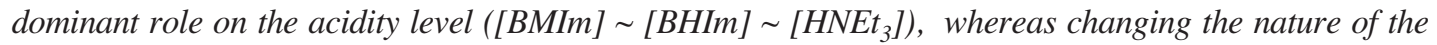
anion of the ionic liquid may lead to very different acidities $\left(\left[\mathrm{SbF}_{6}\right]>\left[\mathrm{PF}_{6}\right]>\left[\mathrm{BF}_{4}\right]>\left[\mathrm{NTf_{2 }}\right]>[\mathrm{OTf}]\right)$. This "acidity scale" was tentatively compared with an "activity scale" obtained for the dimerization of isobutene into isooctenes. The tendencies concerning the cation effect were confirmed ([BMIm] $\left.[\mathrm{BuMePyrr}] \sim\left[\mathrm{HNEt}_{3}\right]\right)$. The anion effect in only partially validated with a different behaviour for $\mathrm{NTf}_{2}$ type ionic liquids $\left(\left[\mathrm{NTf}_{2}\right] \sim\left[\mathrm{SbF}_{6}\right]>\left[\mathrm{PF}_{6}\right] \sim\left[\mathrm{BF}_{4}\right]>[\mathrm{OTf}]\right)$. By an adequate choice of the ionic liquid, selectivity for isobutene dimers can reach $88 \mathrm{wt} \%$ (at 70\% isobutene conversion) with possible recycling of the catalytic system without loss of activity and selectivity. 


\section{ACRONYMS}

$\begin{array}{ll}\text { IL and ILs } & \text { Ionic Liquid and Ionic Liquids } \\ \mathrm{HB} & \text { Brønsted acid } \\ \text { [BMIm] } & \text { 1-butyl-3-methylimidazolium } \\ \text { [BuMePyrr] } & N, N \text {-butylmethylpyrrolidinium } \\ \left.\text { [HNEt }_{3}\right] & \text { triethylammonium } \\ \text { [BHIm }] & \text { 1-butyl-3-H-imidazolium }\end{array}$

[MeIm $\left.\left(\mathrm{CH}_{2}\right)_{2} \mathrm{OMe}\right]$ 1-methyl-3-(2-methoxy) ethylimidazolium [MeIm $\left.\left(\mathrm{CH}_{2}\right)_{4} \mathrm{SO}_{3} \mathrm{H}\right]$ 1-methyl-3-(2-sulfonic acid)ethylimidazolium $\left[\mathrm{NTf}_{2}\right] \quad\left(\mathrm{CF}_{3} \mathrm{SO}_{2}\right)_{2} \mathrm{~N}^{-}=$bistrifluoromethylsulfonimide or bistriflylimide

[OTf] $\mathrm{CF}_{3} \mathrm{SO}_{3}{ }^{-}=$trifluoromethanesulfonate or triflate

$\mathrm{HNTf}_{2} \quad\left(\mathrm{CF}_{3} \mathrm{SO}_{2}\right)_{2} \mathrm{NH}=$ bistriflylimide acid or bistrifluoromethylsulfonimide acid

HOTf $\quad \mathrm{CF}_{3} \mathrm{SO}_{3} \mathrm{H}=$ triflic acid or trifluoromethanesulfonic acid

MTBE Methyl Tertio Butyl Ether

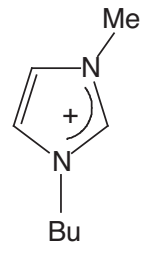

[BMIm]

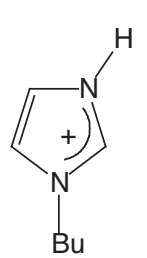

[BMIm]

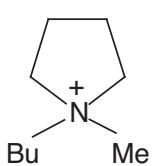

[BuMePyrr]

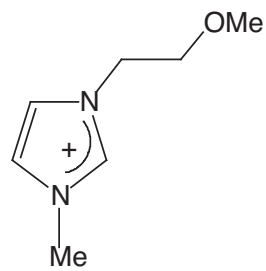

$\left[\mathrm{Melm}\left(\mathrm{CH}_{2}\right)_{2} \mathrm{OMe}\right]$

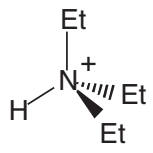

$\left[\mathrm{HNEt}_{3}\right]$

\section{INTRODUCTION}

Ionic liquids (ILs) have been used as alternative solvents in a wide range of catalytic and organic reactions [1-4]. Among them, acid-catalyzed reactions have been the subject of a significant development [5-8]. ILs can be Brønsted and/or Lewis acids with solid-like non-volatility and the potential activity of a liquid phase acids. In many cases, they play a dual role as catalysts and solvents. Compared to organic solvents, they present an increased ability to stabilize charged intermediates, such as carbocations. They can finally offer an improved recovery and recyclability of the catalyst.

In this domain, a lot of references still concern the use of acidic chloroaluminates ILs [1, 3, 9]. Lewis acids such as $\mathrm{AlCl}_{3}, \mathrm{FeCl}_{3}, \mathrm{SbF}_{5}$ etc., can associate with their corresponding anion to form polynuclear anionic species such as $\mathrm{Al}_{2} \mathrm{Cl}_{7}^{-}, \mathrm{Al}_{3} \mathrm{Cl}_{10^{-}}, \mathrm{Fe}_{2} \mathrm{Cl}_{7}^{-}, \mathrm{Sb}_{2} \mathrm{~F}_{11}{ }^{-}$, etc. When associated with dialkylimidazolium cation, these anions produce ILs at low temperature. The acidity strength of the ILs will depend on their composition. They can be made "neutral", acidic or even superacidic (by addition of a proton source) which further extends their reactivity domain [6]. Despite their advantages, acidic chloroaluminates suffer from being extremely oxophilic with an acidity sometimes difficult to control. For these reasons, non-chloroaluminate ionic liquids, supposedly air and moisture stable, have proven to be attractive alternative media for Lewis acid catalyzed reactions [3]. As an example, considerable attention has been focused on the use of metal salts such as lanthanide or scandium triflates in ILs. As they are considered as water tolerant, the range of applications of Lewis catalyzed reactions in ILs could be extended to the transformation of polar compounds.

In addition to Lewis acidic ILs, Brønsted acidic ILs systems were also investigated [6]. In this case, the Brønsted acidity can originate from different ways. First, air-stable nonchloroaluminate ILs can be simply used as solvents for catalytic amounts of protic acids [10]. The acidity can be modulated by controlling both the nature and concentration of the acid as well as the nature of the IL. In a previous publication, we have presented a simple method based on the Hammett acidity function for evaluating the acidity of an IL containing a given amount of Brønsted acid [11]. This method, based on colored indicators and UV-Visible measurements, needs however to be considered with caution since we recently discovered that, as a consequence of the likely non-dissociating character of ILs, the acidity measurements are shifted with respect to the actual acidity $[12,13]$. Sometimes, ILs themselves can also display a Brønsted acidity. They are then used as dual solvents and catalysts. A subset of this non-chloroaluminate ILs are Protic Ionic Liquids (PILs) $[7,14,15]$. They are easily produced through the combination of a Brønsted acid and a base. In the case of strong acids, such as triflic or bis-triflylimide acids, and bases such as alkylimidazole, the proton binds strongly to the nitrogen atom to form alkylimidazolium based ILs. Although the degree of ionicity of these ILs is still the subject of controversies, these "Protic Ionic Liquids" have recently gained increasing interest. ILs have also been designed to be Brønsted acids by covalently tethering an acid group on the cationic part of the ionic liquids $[16,17]$. Sulfonic or carboxylic acids have for example been grafted on the imidazolium cation leading to functionalized "Task-Specific-Ionic Liquids" $[18,19]$. 
If a lot of references deal with the applications of ILs in acid-base reactions, very little is known about the acidityactivity relationship in comparison with conventional liquids and solid acids. In this study, we have investigated various ILs to which a known content of acid has been added. For each solvent, the "apparent" acidity was measured and a reaction involving an acid catalyzed organic synthesis was tested. As catalytic acidic reaction, we have chosen to examine the dimerization of isobutene. From an industrial point of view, this reaction is of interest to produce isooctenes that can further be hydrogenated into isooctanes, an ideal octane booster additives for the reformulated gasoline pool $[20,21]$ as well as a possible alternative for MTBE [22]. From a scientific point of view, the challenge is then to fine tune the acidity level of the catalyst to optimize the isooctenes selectivity while maintaining good isobutene conversion. A further question we would like to answer, at least partially: for the dimerization of isobutene, is there a direct relationship between activity and acidity or not?

\section{RESULTS AND DISCUSSIONS}

\section{CONSIDERATIONS ABOUT THE ACIDITY LEVEL}

\subsection{Introduction}

If one wishes to find a relationship between the activity and the acidity of a catalytic medium, the first problem to be solved is to evaluate properly the actual acidity level of the medium where the reaction will occur. In this context, it is important to recall what we mean by "Brønsted acidity level" and what is his role. As emphasized by Tremillon [23] and considering the classical relationship presented in Equation (1), a $\mathrm{pH}$ acidity scale in a given solvent $(s)$ corresponds to the chemical potential of the proton in that solvent, one unit of $\mathrm{pH}$ corresponding to one unit of $-\mu_{\mathrm{s}} / R T$.

$$
\mu_{\mathrm{H}+}=\mu_{\mathrm{H}+}^{0}+R T \log \mathrm{a}_{\mathrm{H}+},
$$

The origin of the scale, $\mathrm{pH}=0$, is the standard state $\mu_{\mathrm{H}+}^{0}$. This standard chemical potential depends on the solvation state of the proton and is lower as the solvation is stronger (i.e. the solvent is more basic). Clearly, $\mu_{\mathrm{H}+}^{0}$ varies for each solvent and the variation of $\mu_{\mathrm{H}+}^{0}$ from one solvent to another has been connected to the transfer activity coefficient $\Gamma_{\mathrm{H}+}$ [23]. As direct consequence, the acidity level of a given solution containing a certain amount of protons will depend both on the proton solvation extent $\left(\mu^{0}\right)$ and of course on the proton content. In non-aqueous solvents, this last term is complicated by the fact that its activity may differ from its concentration as in aqueous solution but also by the fact that the solvent may not be totally dissociating. In this latter case, ions pairs formation will reduce further the active solvated proton content.

Based on these considerations, it is anticipated that a straightforward relationship between the acidity level and the catalytic properties will be difficult to establish in ionic liquids. The catalytic activity may indeed depend first on the actual state of the proton, strongly solvated of not. The less it is solvated, the more its acidic character will be expressed in the reaction. Secondly, the available proton concentration may also play an important role on the reaction. Optimal catalytic reaction conditions will then be affected by both factors, solvation and concentration: for instance, a given reaction may require a high proton content to occur at a reasonable rate but, at the same time, the solvent could be such that the protons do not have the right acidic level to avoid unwanted side reactions, resulting then into an decrease of selectivity.

\subsection{The Method for Evaluating the Brønsted Acidity in lonic Liquids and its Limitations}

An apparently simple way of measuring the Brønsted acidity of ionic liquids is to determine the Hammett acidity functions, using UV-Visible spectroscopy. In the present case, this method consists of evaluating the protonation extent of uncharged indicator bases (named I) in the solution, in terms of the measurable ratio $[\mathrm{I}] /\left[\mathrm{IH}^{+}\right]$. The chosen indicators (denoted below as CI) belong to the same chemical family, mainly substituted nitroanilines. As recall, in a given solvent $(s)$, the Hammett function $\left(\mathrm{H}_{0}\right)$ is defined as in Equation (2) and (3):

$$
\mathrm{H}_{0}=\mathrm{pKa}_{\mathrm{I}, \mathrm{aq}}+\log \left([\mathrm{I}]_{\mathrm{S}} /\left[\mathrm{IH}^{+}\right]_{\mathrm{S}}\right)
$$

which can also be written as:

$$
\mathrm{H}_{0}=-\log a\left(\mathrm{H}^{+}{ }_{\mathrm{aq}}\right)-\log \gamma(\mathrm{I}) / \gamma\left(\mathrm{IH}^{+}\right)-\log \Gamma(\mathrm{I}) / \Gamma\left(\mathrm{IH}^{+}\right)
$$

where $\mathrm{pKa}_{\mathrm{I}, \mathrm{aq}}$ is the $\mathrm{pKa}$ value of the indicator referred to an aqueous solution, $\left[\mathrm{IH}^{+}\right]_{\mathrm{S}}$ and $[\mathrm{I}]_{\mathrm{S}}$ are the molar concentrations of respectively the protonated and unprotonated forms of the indicator in the solvent $s$ (measured from the UV-Visible spectrum), $\gamma$ are the activity coefficients and $\Gamma$ the transfer activity coefficients from water to the solvent $s$. This method suffers however from a few limitations. At first, the solvent is assumed as being totally dissociating and consequently, the known pKa values of the indicators are also assumed as valid. There are indications in the literature that this is probably not the case [24-28]. As already proposed by Bruckenstein [29] a long time ago for acetic acid solutions, we have shown however that this problem can be partially overcome also in ionic liquids, by defining the Hammett function as an "apparent" acidity function $[12,13]$. The important conclusion is that although the measured acidity level in a given solvent should be lowered as a result of the 


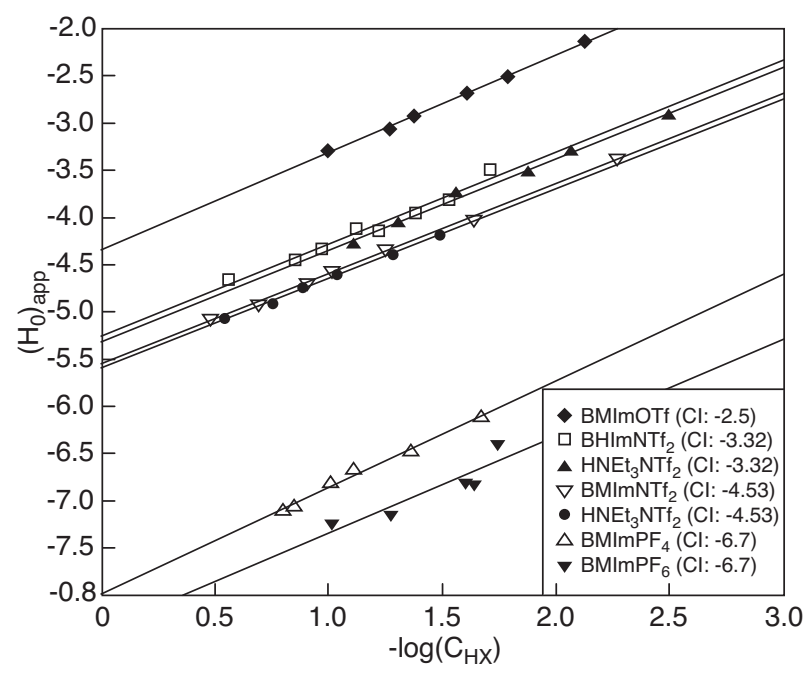

Figure 1

Apparent Hammett acidity functions as a function of $\mathrm{HNTf}_{2}$ or HOTf concentrations in a series of ionic liquids: comparison of the accessible acidity levels.

The Coloured Indicators (CI) are characterized by their pKas.

association process, the order of the relative acidities in not too different solvents is probably maintained. Secondly, Equation (2) shows clearly that $\mathrm{H}_{0}$ is not strictly equivalent to the $\mathrm{pH}[23,30,31]$. This would be the case if one assumes that the concentrations are dilute enough $(\gamma=1)$ and that the ratio of the transfer activity coefficients of both $\mathrm{I}$ and $\mathrm{HI}^{+}$is unity and solvent independent. This latter requirement is met however by choosing indicator couples of very similar chemical structures. In that case, the ratios of the transfer activity coefficients, if not unity, can still be considered as constant, resulting into a slight but constant shift in the acidity function. This is why, despite its limitations, we have chosen to keep the Hammett function as a probe for acidity and semi-quantitative acidity comparison purposes. We have then measured the apparent Hammett acidity functions in a series of ionic solvents to which were added similar but variable contents of $\mathrm{HNTf}_{2}$ or HOTf, two acids assumed in a first step as behaving as strong acids [12]. The overall results are presented in Figure 1 where the "apparent" $\mathrm{H}_{0}$ is plotted versus the acid content.

The following acidities sequence was found, shown as decreasing acidity levels: $[\mathrm{BMIm}]\left[\mathrm{SbF}_{6}\right]>[\mathrm{BMIm}]\left[\mathrm{PF}_{6}\right]>$ $[\mathrm{BMIm}]\left[\mathrm{BF}_{4}\right]>[\mathrm{BHIm}]\left[\mathrm{NTf}_{2}\right]=[\mathrm{BMIm}]\left[\mathrm{NTf}_{2}\right]=$ $\left[\mathrm{HNEt}_{3}\right]\left[\mathrm{NTf}_{2}\right]>[\mathrm{BMIm}][\mathrm{OTf}]$. That sequence was recently confirmed for the systems $[\mathrm{BMIm}]\left[\mathrm{BF}_{4}\right],[\mathrm{BMIm}]\left[\mathrm{NTf}_{2}\right]$ and [BMIm] [OTf] by using an hydrogen electrode for measuring acidities [33]. It will then be compared with the catalytic results obtained for isobutene dimerization. This reaction is a good example to describe the level of Brønsted acidity for a given catalytic system. The performances will be described on the basis of conversion of isobutene and selectivity in dimers.

\section{SELECTIVE DIMERIZATION OF ISOBUTENE}

\subsection{Introduction}

The dimerization of isobutene by acid catalyzed systems proceeds with a cationic mechanism (Scheme 1) [20]. It first involves the formation of tertiary carbocation by transfer of a proton from the acid catalyst to the isobutene molecule. This carbocation then reacts with another molecule of isobutene to form a second tertiary carbocation. Termination occurs when the dimeric carbocation loses a proton and forms the two isomers: 2,4,4-trimethyl-1-pentene or 2,4,4-trimethyl-2pentene. When the second tertiary carbocation is reasonably stable, this termination reaction may become slower than the chain propagation. The reaction can further oligomerize to C12 trimers, C16 tetramers, or even higher oligomers in a similar fashion.

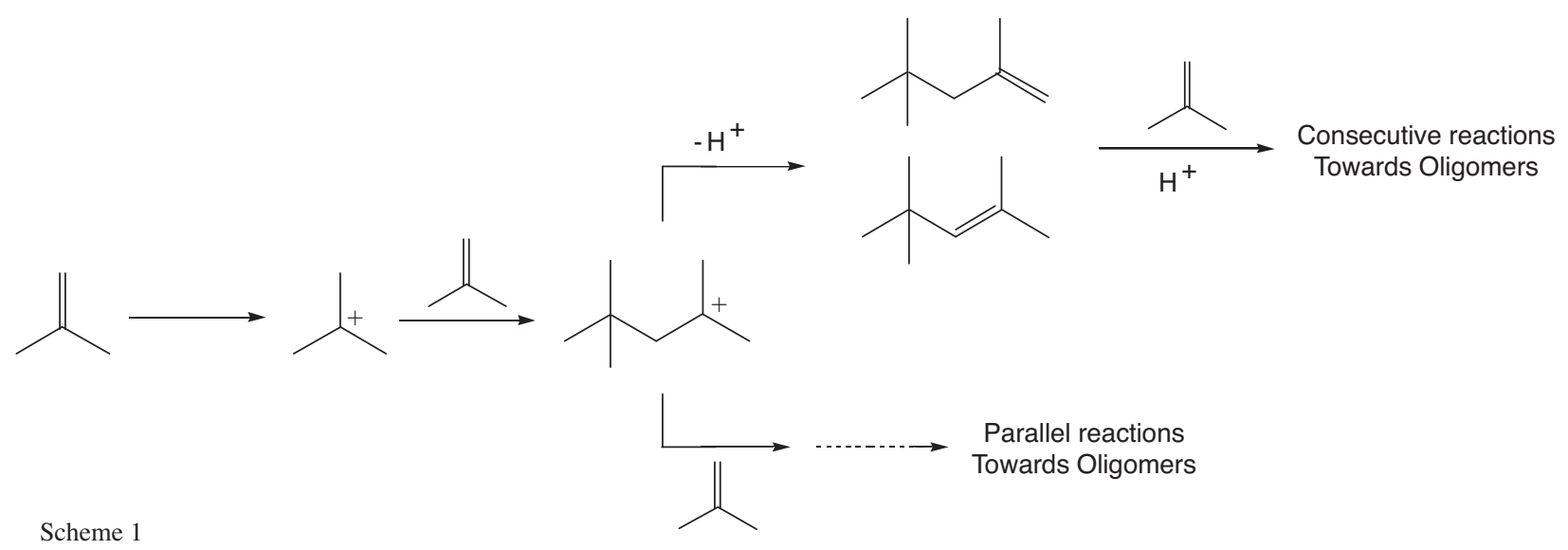

Mechanism of acid catalyzed oligomerization of isobutene. 
The conventional approach to catalyze this reaction uses solid acids. The acids most typically used in the industry are silica supported phosphoric acid (InAlk process proposed by $\mathrm{UOP}$ ) and ion exchange resins (isoether DEP process licensed by Snamprogetti and NExOCTANE process available from Neste Oil) $[20,32,34]$. It is interesting to note that in both cases, oxygenated additives (tert-butyl alcohol, water or methanol) are used to control the acidity level and then the isobutene dimer selectivity [35]. Indeed, the poor controllability in product distribution may lead to rapid deactivation of the solid catalysts especially when high molecular weight oligomers are produced. These high oligomers generally poison the active sites and block the pores of the solid catalysts. The use of acidic ionic liquids in this context can be very interesting. From a process point of view, it can permit a good immobilization of the catalyst with a possible recycling of the IL catalytic phase. Furthermore, because of the low solubility of the C8 dimers in the IL phase, consecutive reactions and formation of higher oligomers can be limited. Finally, the versatility of ILs through the "cation/anion" association, gave us more opportunities for the fine tuning of solvation effects, as discussed in Section 1.1.

Up to now, only few reports deal with the use of "ionic liquids/Brønsted acid" system for the selective isobutene dimerization. In the patent literature, IFP has first described a catalytic composition that comprises at least one Brønsted acid, designed $\mathrm{HB}$, dissolved in a non aqueous ionic liquid medium of general formula $\mathrm{Q}^{+} \mathrm{A}^{-}[10]$. The reaction was performed at $25^{\circ} \mathrm{C}$ with different "IL/HB" associations. When using "[BMIm][OTf]/HOTf" catalytic system, isobutene conversion reached $70 \%$ with a dimer selectivity around 88\%. In 2003, Deng et al. described the use of $\mathrm{SO}_{3} \mathrm{H}-$ functionnalized imidazolium-based ILs for oligomerization of various olefins [35]. At $120^{\circ} \mathrm{C}$ in the presence of 1-(4-sulfonic acid)butyl-3-methylimidazolium triflate, the conversion of isobutene after $6 \mathrm{~h}$ was $68 \%$ with a dimer selectivity around $87 \%$. Isobutene trimers $(12 \%)$ as well as tetramers $(1 \%)$ were also produced. In this work, an interesting effect of the alkyl chain length in the 1-(4-sulfonic acid)butyl-3-alkylimidazolium cation was demonstrated. The increase in the non polar character of the ionic liquid favored the formation of higher oligomers. This result can be linked with the increased solubility of isobutene and isobutene dimers while increasing the non-polar character of the IL.

\subsection{Influence of Reaction Parameters on the Catalytic Performances}

In a first series of experiments, the effect of some reaction parameters were studied. The reaction time was investigated at $25^{\circ} \mathrm{C}$ for the "[BMIm] $\left[\mathrm{NTf}_{2}\right] / \mathrm{HNTf}_{2}$ " catalytic mixture. It appeared appropriate to realize the systematic study on this couple " $[\mathrm{BMIm}]\left[\mathrm{NTf}_{2}\right] / \mathrm{HNTf}_{2}$ " essentially because this ionic liquid can be produced on large scale with a good reproducibility and purity. Results are given in Table 1 . The isobutene conversion varies from $55 \%$ to $84 \%$ and $97 \%$ as the reaction time was increased respectively from 2,7 and $20 \mathrm{~min}$. While increasing the reaction time, the selectivity for isobutene dimers decreases from $55 \%, 47 \%$ to $41 \%$ respectively (entries $1,2,3$ ). Not surprisingly, the decrease of temperature from $25^{\circ} \mathrm{C}$ to $0^{\circ} \mathrm{C}$ dramatically affects the isobutene conversion keeping the selectivity quite identical (entries 5 and 6). More interesting is the role of the acid concentration in the ionic liquid. Very low concentrations of $\operatorname{HNTf}_{2}$ in $[\mathrm{BMIm}]\left[\mathrm{NTf}_{2}\right]$ can be used to access good isobutene conversions (entry 4). Then, an increase in the acid concentration essentially yields to a decrease in dimer selectivity (entries 3 and 5). Due to higher acidity levels, production of higher oligomers would be favored.

TABLE 1

Effect of reaction time, acid concentration and temperature for "[BMIm] $\left[\mathrm{NTf}_{2}\right] / \mathrm{HNTf}_{2}$ "

\begin{tabular}{|c|c|c|c|c|c|c|c|c|}
\hline \multirow{2}{*}{ Entry } & \multirow{2}{*}{$\begin{array}{c}\mathrm{HNTf}_{2} \\
\left(\mathrm{~mol}^{-L^{-1}}\right)\end{array}$} & \multirow{2}{*}{$\begin{array}{l}\text { Time } \\
(\mathrm{min})\end{array}$} & \multirow{2}{*}{$\begin{array}{c}\text { Temperature } \\
\left({ }^{\circ} \mathrm{C}\right)\end{array}$} & \multirow{2}{*}{$\begin{array}{l}\text { Conv. } \\
\text { (\%wt) }\end{array}$} & \multicolumn{4}{|c|}{ Selectivities (\%wt) } \\
\hline & & & & & $\mathrm{C} 8$ & $\mathrm{C} 12$ & C16 & HBP* \\
\hline 1 & 0.013 & 2 & 25 & 55 & 55 & 40 & 5 & $<1$ \\
\hline 2 & 0.014 & 7 & 25 & 84 & 47 & 46 & 6 & $<1$ \\
\hline 3 & 0.014 & 20 & 25 & 97 & 41 & 51 & 8 & $<1$ \\
\hline 4 & 0.003 & 12 & 25 & 85 & 57 & 38 & 5 & $<1$ \\
\hline 5 & 0.025 & 22 & 25 & 99 & 35 & 56 & 9 & $<1$ \\
\hline 6 & 0.026 & 15 & 0 & 55 & 40 & 51 & 9 & $<1$ \\
\hline
\end{tabular}

Reaction conditions: [BMIm][NTf ${ }_{2}$ ( $\left.4 \mathrm{~mL}\right)$; isobutene $(20 \mathrm{~mL}, 11.2 \mathrm{~g}, 0.20 \mathrm{~mol})$; stirring rate $(1000 \mathrm{rpm}) ; * \mathrm{HBP}=$ higher boiling point oligomers.

\subsection{Influence of the lonic Liquid Nature}

In a second series of experiments, the influence of the IL anion was studied (Tab. 2). The strong $\mathrm{HNTf}_{2}$ acid has been chosen for a comparison with the relative acidity scale presented before. When using $[\mathrm{BMIm}]\left[\mathrm{NTf}_{2}\right]$ (entry 7) and very low $\mathrm{HNTf}_{2}$ concentration $\left(0.013 \mathrm{~mol}^{-\mathrm{L}^{-1}}\right)$, high isobutene conversion can be observed in a very short reaction time. The selectivity for the dimerization products in [BMIm] $\left[\mathrm{NTf}_{2}\right]$ remains low at $47 \%$, as formation of isobutene trimers are observed in large amount. Under the same acid concentrations, we did not observed any reaction in a non dissociating and non coordinating organic solvent like heptane (entry 16). More surprisingly, no isobutene conversion was observed in water (entry 17). In a certain manner, this last result demonstrates the solvating effect of water with respect to the proton. The effect of water on the acidity level of a strong acid in ILs was demonstrated by UVVisible measurements in our previous work [11]. Addition of water in a given "IL/HB" association decreases considerably the acidity level of the proton. Others ionic liquids were also evaluated under the same $\operatorname{HNTf}_{2}$ concentration. Less 
satisfactory results were obtained using $[\mathrm{BMIm}]\left[\mathrm{SbF}_{6}\right]$ (entry 8) with lower conversion and formation of higher oligomers, while no activity was observed for the others (entries 9,11 and 13). Increasing amounts of $\mathrm{HNTf}_{2}$ were then added and, for $[\mathrm{BMIm}]\left[\mathrm{PF}_{6}\right]$ and $[\mathrm{BMIm}]\left[\mathrm{BF}_{4}\right]$ (entries 10 and 12 ), oligomerization of isobutene is observed with $\mathrm{HNTf}_{2}$ concentration around $0.05 \mathrm{~mol} . \mathrm{L}^{-1}$. After $20 \mathrm{mn}$, isobutene conversion reaches $67 \%$ and $45 \%$ respectively but with very low selectivities for dimer products (9-11\%).

\section{TABLE 2}

Effect of the nature of the ionic liquid anions in "[BMIm][Anion]/HNTf ${ }_{2}$ "

\begin{tabular}{|c|c|c|c|c|c|c|c|c|}
\hline \multirow{2}{*}{ Entry } & \multirow{2}{*}{ Ionic Liquid } & \multirow{2}{*}{$\begin{array}{c}\text { HNTf }_{2} \\
\left(\mathrm{~mol}^{-1} \mathrm{~L}^{-1}\right)\end{array}$} & \multirow{2}{*}{$\begin{array}{l}\text { Time } \\
(\mathrm{min})\end{array}$} & \multirow{2}{*}{$\begin{array}{l}\text { Conv. } \\
(\% \mathrm{wt})\end{array}$} & \multicolumn{4}{|c|}{ Selectivities (\% wt) } \\
\hline & & & & & $\mathrm{C} 8$ & $\mathrm{C} 12$ & C16 & HBP* \\
\hline 7 & {$[\mathrm{BMIm}]\left[\mathrm{NTf}_{2}\right]$} & 0.014 & 7 & 84 & 47 & 46 & 6 & $<1$ \\
\hline 8 & {$[\mathrm{BMIm}]\left[\mathrm{SbF}_{6}\right]$} & 0.013 & 7 & 43 & 23 & 49 & 20 & 8 \\
\hline 9 & {$[\mathrm{BMIm}]\left[\mathrm{PF}_{6}\right]$} & 0.013 & 7 & 0 & - & - & - & - \\
\hline 10 & {$[\mathrm{BMIm}]\left[\mathrm{PF}_{6}\right]$} & 0.050 & 20 & 67 & 11 & 36 & 29 & 25 \\
\hline 11 & {$[\mathrm{BMIm}]\left[\mathrm{BF}_{4}\right]$} & 0.013 & 7 & 0 & - & - & - & - \\
\hline 12 & {$[\mathrm{BMIm}]\left[\mathrm{BF}_{4}\right]$} & 0.051 & 20 & 45 & 9 & 35 & 26 & 31 \\
\hline 13 & [BMIm][OTf] & 0.013 & 7 & 0 & - & - & - & - \\
\hline 14 & [BMIm][OTf] & 0.133 & 20 & 54 & 87 & 11 & 2 & 0 \\
\hline 15 & {$[\mathrm{BMIm}]\left[\mathrm{CH}_{3} \mathrm{SO}_{4}\right]$} & 0.247 & 20 & 0 & - & - & - & - \\
\hline 16 & Heptane & 0.013 & 7 & 0 & - & - & - & - \\
\hline 17 & Water & 0.013 & 7 & 0 & - & - & - & - \\
\hline
\end{tabular}

Reaction conditions: Ionic liquid $(4 \mathrm{~mL})$; isobutene $(20 \mathrm{~mL} ; 11.2 \mathrm{~g} ; 0.20 \mathrm{~mol})$; stirring rate $(1000 \mathrm{rpm})$; temperature $25^{\circ} \mathrm{C}$; ${ }^{*} \mathrm{HBP}=$ higher isobutene oligomers

From this series of experiments it is possible to establish a "relative activity scale". Based on the isobutene conversion,

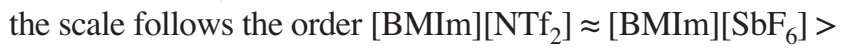
$[\mathrm{BMIm}]\left[\mathrm{PF}_{6}\right] \approx[\mathrm{BMIm}]\left[\mathrm{BF}_{4}\right]>[\mathrm{BMIm}][\mathrm{OTf}]>>$ $[\mathrm{BMIm}]\left[\mathrm{CH}_{3} \mathrm{SO}_{4}\right]$. In view of all these results, it is surprising that the reaction activity does not follow exactly the "apparent $\mathrm{H}_{0}$ acidity scale" we have previously estimated by UV-Visible measurements. One must keep in mind that the experimental catalytic activity order discussed here is certainly the result of various parameters such as chemical contributions but also physical contributions (isobutene solubility in the ionic liquid phase...). Another important aspect for the strict comparison of both scales concerns the ionic liquid impurity level. As water can act as a base for a given "IL/HB" system, it was taken into account for our interpretation but it may not represent the total amount of basic impurities in the ionic liquid. As a consequence, a direct correlation with the Hammett acidity scale is then difficult. Nevertheless, we discuss below some hypotheses allowing to explain the obtained results.

As reported in Table 2, the most acidic mixtures $[\mathrm{BMIm}]\left[\mathrm{SbF}_{6}\right] / \mathrm{HNTf}_{2}$, [BMIm] $\left[\mathrm{PF}_{6}\right] / \mathrm{HNTf}_{2}$ and $\left.\left.[\mathrm{BMIm}]\right] \mathrm{BF}_{4}\right] /$
$\mathrm{HNTf}_{2}$ do not lead to the highest conversions and to the best performances. We then propose here that the optimal reaction conditions are the result of a compromise since the selectivities and the conversion extents are two different properties which seem to proceed from two different origins:

- although a high enough acidity level is needed for the reaction to occur, the low selectivities would be the result of the too high acidity levels reached by the proton in $[\mathrm{BMIm}]\left[\mathrm{BF}_{4}\right],\left[\mathrm{PF}_{6}\right]$ and $\left[\mathrm{SbF}_{6}\right]$, as measured from their respective Hammett functions. First, when the acidity level is too high, the protonation of the dimers may occur resulting into the formation of oligomers by consecutive reactions (Scheme 1). This hypothesis however is unlikely in our case as the reaction occurs in a biphasic medium. Since the dimers are less soluble in the ILs than the monomer, they can be selectively extracted in the upper organic phase as soon as they are formed, and this is not in favour of their subsequent reaction in the IL. Secondly, in these ionic liquids, protons are less solvated $\left(\mathrm{BF}_{4}^{-}, \mathrm{PF}_{6}{ }^{-}\right.$and $\mathrm{SbF}_{6}{ }^{-}$are less coordinating anions) and then less stabilized. Consequently, it is more difficult for the isooctene carbocation to loose its proton and for the termination step to occur. We can then assume that parallel reactions (Scheme 1) are facilitated which leads to a decrease of the selectivity;

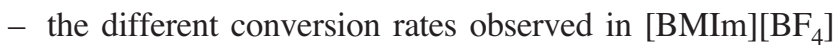
and $[\mathrm{BMIm}]\left[\mathrm{PF}_{6}\right]$ with respect to $[\mathrm{BMIm}]\left[\mathrm{SbF}_{6}\right]$ and $[\mathrm{BMIm}]\left[\mathrm{NTf}_{2}\right]$ are possibly coming from a higher basic impurities level in the two first mentioned solvents. It is then simply necessary to first neutralize these impurities before the solvent becomes acidic enough and the reaction could start.

In view of these propositions, the results for the dimerization of isobutene could be explained as follows. In the highest acidity media and when the problem of basic impurities is overcome by addition of some acid in excess, a large part of oligomers are formed because the proton is too active (as discussed above). On the other side, for the [BMIm] [OTf]/HNTf 2 , as the acidity is lower than in fluorinated solutions and even than in $[\mathrm{BMIm}]\left[\mathrm{NTf}_{2}\right] / \mathrm{HNTf}_{2}$, the $\mathrm{HNTf}_{2}$ concentration needs to be increased up to $0.133 \mathrm{~mol} . \mathrm{L}^{-1}$ in order to observe an isobutene conversion (entry 14). At this concentration, the isobutene conversion is low (54\%) but it proceeds with a very good dimer selectivity of $87 \%$. In this case, there is large amount of solvated proton, not too acidic thus inducing a termination step with less parallel and consecutive reactions. Finally, even with very large quantities of $\mathrm{HNTf}_{2}$, no activity was detected when using the $[\mathrm{BMIm}]\left[\mathrm{CH}_{3} \mathrm{SO}_{4}\right]$ as ionic liquid. The explanation is that the proton strength is here too low, certainly buffered by the solvation effect of the more strongly coordinating $\mathrm{CH}_{3} \mathrm{SO}_{4}{ }^{-}$anions; in that case, a satisfactory acidity level cannot be reached, even with very high $\mathrm{HNTf}_{2}$ concentration.

In summary, we propose that the catalytic activity results from the combination of two factors, as already discussed in 
our introduction on the acidity level. It is clear that a sufficient acidity level must be reached to protonate the isobutene. Regarding a catalytic reaction, this concept is somewhat more complex however since the acidity level depends on both the solvated proton content (relative activity) and the coordinating strength of the IL anion (intrinsic activity of the proton). First, a too acidic proton induces the production of oligomers, decreasing the selectivity; on the contrary, an insufficient content of acidic protons prevents the isobutene conversion.

The influence of the ILs cations was then evaluated regarding the anion $\mathrm{NTf}_{2}^{-}(\mathrm{Tab} .3)$. If we compare the results obtained with [BMIm] $\left[\mathrm{NTf}_{2}\right]$, [BuMePyrr] $\left[\mathrm{NTf}_{2}\right]$ and $\left[\mathrm{HNEt}_{3}\right]\left[\mathrm{NTf}_{2}\right]$ (entries 18,19 and 20), the effect of the cation seems to be very limited. Only slight changes for the dimer selectivities in $\left[\mathrm{HNEt}_{3}\right]\left[\mathrm{NTf}_{2}\right]$ are observed. Under the experimental conditions applied, no significant effect of the $\mathrm{N}-\mathrm{H}$ proton in the $\left[\mathrm{HNEt}_{3}\right]$ cation was detected. Without addition of $\mathrm{HNTf}_{2}$ (entry 21), no activity was observed which is consistent with the very low acidity level of the $\mathrm{N}-\mathrm{H}$ proton in $\left[\mathrm{HNEt}_{3}\right]^{+}$(demonstrated by UV-Visible measurements).

TABLE 3

Effect of the nature of the ionic liquid cation in "[Cation] $\left[\mathrm{NTf}_{2}\right] / \mathrm{HNTf}_{2}$ "

\begin{tabular}{|c|c|c|c|c|c|c|c|c|}
\hline \multirow{2}{*}{ Entry } & \multirow{2}{*}{ Ionic Liquid } & \multirow{2}{*}{$\begin{array}{c}\text { HNTf }_{2} \\
\left(\mathrm{~mol}^{-1} \mathrm{~L}^{-1}\right)\end{array}$} & \multirow{2}{*}{$\begin{array}{l}\text { Time } \\
(\mathrm{min})\end{array}$} & \multirow{2}{*}{$\begin{array}{l}\text { Conv. } \\
(\% \mathrm{wt})\end{array}$} & \multicolumn{4}{|c|}{ Selectivities (\% wt) } \\
\hline & & & & & C8 & $\mathrm{C} 12$ & C16 & $\mathrm{HBP}^{*}$ \\
\hline 18 & {$[\mathrm{BMIm}]\left[\mathrm{NTf}_{2}\right]$} & 0.014 & 7 & 84 & 47 & 46 & 6 & $<1$ \\
\hline 19 & {$[\mathrm{BuMePyrr}]\left[\mathrm{NTf}_{2}\right]$} & 0.013 & 7 & 79 & 45 & 48 & 7 & $<1$ \\
\hline 20 & {$\left[\mathrm{HNEt}_{3}\right]\left[\mathrm{NTf}_{2}\right]$} & 0.013 & 7 & 82 & 55 & 40 & 5 & $<1$ \\
\hline 21 & {$\left[\mathrm{HNEt}_{3}\right]\left[\mathrm{NTf}_{2}\right]$} & 0 & 60 & 0 & - & - & - & - \\
\hline
\end{tabular}

Reaction conditions: Ionic liquid $(4 \mathrm{~mL})$; isobutene $(20 \mathrm{~mL}, 11.2 \mathrm{~g}, 0.20 \mathrm{~mol})$; stirring rate $(1000 \mathrm{rpm})$; temperature $25^{\circ} \mathrm{C}$; $* \mathrm{HBP}=$ higher isobutene oligomers.

Even with very low acid concentration, the isobutene dimer selectivity observed in $\mathrm{NTf}_{2}$ type ILs does not exceed $55 \%$. Decreasing of acid concentration to lower values only yields to non reproducible results as the system becomes too sensitive to the presence of impurity traces. Nevertheless, from the results presented in Table 2, one can observe that the dimer selectivity can be improved by a careful control of the solvation effect (entry 14). This can be achieved by changing the IL anion. With OTf based ILs, high dimer selectivity can be obtained, but higher $\mathrm{H}^{+}$concentration are needed.

\subsection{Influence of the Brønsted Acid Added to the ILs}

Paying attention to the results presented above in Table 2, one can observe that both the activity (isobutene conversion) and the dimer selectivity are directed by a careful choice of the nature of the ionic liquid. Another parameter which can also aid for the control of activity and selectivity is the nature of the acid added and its concentration in the IL. Depending on its strength, one can expect variation of the results obtained (Tab.4).

TABLE 4

Influence of the acid nature on activity and selectivity in [BMIm] $\left[\mathrm{NTf}_{2}\right]$

\begin{tabular}{|c|c|c|c|c|c|c|c|c|}
\hline \multirow{2}{*}{ Entry } & \multirow{2}{*}{ Ionic Liquid } & \multicolumn{2}{|c|}{ Added Acid } & \multirow{2}{*}{$\begin{array}{l}\text { Time } \\
(\mathrm{min})\end{array}$} & \multirow{2}{*}{$\begin{array}{l}\text { Conv. } \\
\text { (\% wt) }\end{array}$} & \multicolumn{3}{|c|}{$\begin{array}{l}\text { Selectivities } \\
(\% \mathrm{wt})\end{array}$} \\
\hline & & nature & $\left(\mathrm{mol} . \mathrm{L}^{-1}\right)$ & & & $\mathrm{C} 8$ & $\mathrm{C} 12$ & C16 \\
\hline 22 & {$[\mathrm{BMIm}]\left[\mathrm{NTf}_{2}\right]$} & $\mathrm{HNTf}_{2}$ & 023 & 22 & 100 & 23 & 64 & 12 \\
\hline 23 & {$[\mathrm{BMIm}]\left[\mathrm{NTf}_{2}\right]$} & HOTf & 0.012 & 9 & 99 & 27 & 57 & 12 \\
\hline 24 & {$[\mathrm{BMIm}]\left[\mathrm{NTf}_{2}\right] *$} & $\mathrm{CH}_{3} \mathrm{SO}_{3} \mathrm{H}$ & 0.154 & 20 & 65 & 75 & 22 & 1 \\
\hline 25 & {$[\mathrm{BMIm}]\left[\mathrm{NTf}_{2}\right]$} & $\mathrm{CF}_{3} \mathrm{CO}_{2} \mathrm{H}$ & 687 & 180 & 30 & 77 & 18 & 2 \\
\hline 26 & {$[\mathrm{BMIm}]\left[\mathrm{NTf}_{2}\right]$} & $\mathrm{CH}_{3} \mathrm{CO}_{2} \mathrm{H}$ & 10.547 & 60 & 0 & - & - & - \\
\hline
\end{tabular}

Reaction conditions: Ionic liquid $(6 \mathrm{~mL})$; isobutene $(30 \mathrm{~mL}, 16.8 \mathrm{~g}, 0.30 \mathrm{~mol})$; stirring rate $(1000 \mathrm{rpm})$; temperature $25^{\circ} \mathrm{C}$; * Use of $4 \mathrm{~mL}$ of IL instead of $6 \mathrm{~mL}$ and $20 \mathrm{~mL}$ of isobutene instead of $30 \mathrm{~mL}$. We assumed that the changes in the ionic liquids volumes would not have significant impact on the results observed.

As observed for $\mathrm{HNTf}_{2}$, only low catalyst loading is necessary to reach high conversion in a very short reaction time. The control of this acidic system is difficult and generally affords low dimer selectivity. Changing this acid to HOTf does not seem to be the right option. In [BMIm] $\left[\mathrm{NTf}_{2}\right]$ ionic liquid, HOTf exhibits practically the same results. This point had been stressed in our previous paper on the measurements of Hammett function [11]. For the same $\mathrm{H}^{+}$ concentration, the Hammett functions were -4.80 and -4.60 for $\mathrm{HNTf}_{2}$ and HOTf respectively. When moving to the less acidic $\mathrm{CH}_{3} \mathrm{SO}_{3} \mathrm{H}$, the acid concentration must be much increased to reach reasonable isobutene conversion but better dimer selectivity are also obtained (entry 24). Similar results was obtained for $\mathrm{CF}_{3} \mathrm{CO}_{2} \mathrm{H}$ in $[\mathrm{BMIm}]\left[\mathrm{NTf}_{2}\right]$ with nevertheless higher acid concentration (entry 25). For acetic acid (entry 26), no conversion was obtained even with high concentration.

\subsection{Recovery and Recyclability of the "IL/HB" System}

On the basis of the preliminary results obtained in Table 2 to Table 4, several attempts to optimize the catalyst recycling were performed. Table 3 indicates that the choice of the $\mathrm{IL}$ cation is not critical. Furthermore, the preliminary results obtained in Table 2 indicate that ionic liquids based on [OTf] anion (e.g. [BMIm][OTf]) correspond to the best compromise in term of activity and selectivity (see Tab. 2 entry 14) when $\mathrm{HNTf}_{2}$ is used as acid. We also demonstrated in Table 4 that $\mathrm{CH}_{3} \mathrm{SO}_{3} \mathrm{H}$ can produce interesting results ( $65 \%$ conversion with $75 \%$ selectivity). Because of the huge difference in term of price between HOTf or $\mathrm{HNTf}_{2}$ and $\mathrm{CH}_{3} \mathrm{SO}_{3} \mathrm{H}$, it appeared judicious to perform the recycling 
experiments using the "[BMIm] [OTf $] / \mathrm{CH}_{3} \mathrm{SO}_{3} \mathrm{H}$ " system. We then performed preliminary experiments (not presented here) to identify the right concentration of $\mathrm{CH}_{3} \mathrm{SO}_{3} \mathrm{H}$ in [BMIm] $\left[\mathrm{CF}_{3} \mathrm{SO}_{3}\right]$ to obtain good conversion and dimers selectivity in a reasonable reaction time. On the basis of these results, and in order to optimize the catalyst recycling process, we developed an analogue acid of $\mathrm{CH}_{3} \mathrm{SO}_{3} \mathrm{H}$ by the grafting of an ionic imidazolium tag. This approach leads to $\left[\mathrm{MeIm}\left(\mathrm{CH}_{2}\right)_{4} \mathrm{SO}_{3} \mathrm{H}\right][\mathrm{OTf}]$. Thanks to its ionic nature, we expected an optimal immobilization and recyclability of the catalytic system. We performed 10 recycling experiments with the results presented in Table 5. Isobutene conversion after $150 \mathrm{mn}$ is stable around $70 \%$ with a dimer selectivity around $90 \%$ which represents the best results obtained in this study. We did not observed any evolution of the ionic liquid volume (which means no accumulation of side products) during our experiments, even after 10 recycles as proposed in Table 5. Comparison of ${ }^{1} \mathrm{H}$ NMR spectra of the ionic liquid phase before and after the recycling series demonstrates the perfect immobilization of the acid in the ionic liquid and its good recyclability.

\section{TABLE 5}

Recycling of "[BMIm][OTf]/[MeIm( $\left.\left(\mathrm{CH}_{2}\right)_{4} \mathrm{SO}_{3} \mathrm{H}\right][\mathrm{OTf}]$ " acidic system

\begin{tabular}{|c|c|c|c|c|c|c|c|}
\hline \multirow[t]{2}{*}{ Entry } & \multirow[t]{2}{*}{ Ionic Liquid } & \multicolumn{2}{|l|}{ Added Acid } & \multirow{2}{*}{$\begin{array}{l}\text { Conv. } \\
\text { (\% } \% \mathrm{t})\end{array}$} & \multicolumn{3}{|c|}{$\begin{array}{c}\text { Selectivities } \\
\text { (\% wt) }\end{array}$} \\
\hline & & nature & mol & & $\mathrm{C} 8$ & C12 & C16 \\
\hline 27 & {$[\mathrm{BMIm}][\mathrm{OTf}]$} & {$\left[\mathrm{MeIm}\left(\mathrm{CH}_{2}\right)_{4} \mathrm{SO}_{3} \mathrm{H}\right][\mathrm{OTf}]$} & 0.012 & 71 & 86 & 14 & $<1$ \\
\hline 28 & Recycle 1 & & & 71 & 87 & 12 & $<1$ \\
\hline 29 & Recycle 2 & & & 71 & 88 & 12 & $<1$ \\
\hline 30 & Recycle 3 & & & 66 & 88 & 12 & $<1$ \\
\hline 31 & Recycle 4 & & & 64 & 88 & 12 & $<1$ \\
\hline 32 & Recycle 5 & & & 68 & 88 & 11 & $<1$ \\
\hline 33 & Recycle 6 & & & 60 & 89 & 10 & $<1$ \\
\hline 34 & Recycle 7 & & & 67 & 89 & 11 & $<1$ \\
\hline 35 & Recycle 8 & & & 61 & 89 & 11 & $<1$ \\
\hline 36 & Recycle 9 & & & 66 & 90 & 10 & $<1$ \\
\hline 37 & Recycle 10 & & & 68 & 90 & 10 & $<1$ \\
\hline
\end{tabular}

Reaction conditions: [BMIm][OTf] $(2 \mathrm{~mL}) ;\left[\mathrm{MeIm}\left(\mathrm{CH}_{2}\right)_{4} \mathrm{SO}_{3} \mathrm{H}\right][\mathrm{OTf}]$

$(\sim 3 \mathrm{~mL}, 4.37 \mathrm{~g}, 0.012 \mathrm{~mol}$ ) added once at the beginning of the reaction; isobutene ( $20 \mathrm{~mL}$ added after each run, $11.2 \mathrm{~g}, 0.20 \mathrm{~mol}$ ); stirring rate (1000 rpm); temperature $25^{\circ} \mathrm{C}$; time $=150 \mathrm{mn}$.

\section{EXPERIMENTAL SECTION}

\subsection{Solvents and Reagents}

All manipulations were performed under an argon atmosphere using standard Schlenk techniques.
HOTf (98\%, Aldrich), $\mathrm{HNTf}_{2}\left(97 \%\right.$, Fluka), $\mathrm{CH}_{3} \mathrm{SO}_{3} \mathrm{H}$ (99.5\%, Aldrich), $\mathrm{CF}_{3} \mathrm{CO}_{2} \mathrm{H}\left(99 \%\right.$, Aldrich), $\mathrm{CH}_{3} \mathrm{CO}_{2} \mathrm{H}$ $(99.8 \%, S D S)$, sodium tetrafluoroborate $(98 \%$, Aldrich), sodium hexafluorophosphate $(99 \%$, Strem), sodium hexafluoro-antimonate (technical grade, Aldrich), ammonium triflate (99\%, Aldrich), lithium bis-(trifluoromethylsulfonyl)imide (99\%, Fluka), butanesultone (99\%, Aldrich) and 2chloroethylmethylether (98\%, Aldrich) were used without further purification. 1-methylimidazole $(99 \%$, Aldrich), 1methylpyrrolidine (97\%, Aldrich) and 1-chlorobutane (99\%, Aldrich) were freshly distilled under reduced pressure prior to use. Dichloromethane was dried using MBraun SPS 800 . Some precursor for ionic liquid synthesis were also obtained from commercial source: triethylamine hydrochloride $(98 \%$, Aldrich), [BMIm] [Cl] (98\%, Solvionic) and [BMIm] $\left[\mathrm{CH}_{3} \mathrm{SO}_{4}\right]$ (high purity, Merck) were used as received unless otherwise indicated.

\subsection{Synthesis and Characterization of Ionic Liquids}

Ionic liquids described in this work were thoroughly purified because of the importance of ionic liquids impurities on both UV-Visible and catalysis results. A great care has been devoted to the purification process. The purified ionic liquids were then characterized for their water, halide, and alkylimidazole or 1-methylpyrrolidine content.

The classical ionic liquids [BMIm][X], [BuMePyrr][X] and $\left[\mathrm{HNEt}_{3}\right][\mathrm{X}]$ (with $\mathrm{X}=\mathrm{BF}_{4}, \mathrm{NTf}_{2}, \mathrm{PF}_{6}, \mathrm{SbF}_{6}, \mathrm{OTf}$ ) were synthesized by anion exchange from their chloride precursor following published procedures [37-39]. For the functionnalized ionic liquids $\left[\mathrm{MeIm}\left(\mathrm{CH}_{2}\right)_{2} \mathrm{OMe}\right]\left[\mathrm{NTf}_{2}\right]$ and $\left[\mathrm{MeIm}\left(\mathrm{CH}_{2}\right)_{4} \mathrm{SO}_{3} \mathrm{H}\right][\mathrm{OTf}]$ details are reported below. All the syntheses were carried out under dry argon and all the products were dried over several days under vacuum $\left(6.10^{-2}\right.$ mbar) at $50-60^{\circ} \mathrm{C}$ before storage.

The ionic liquids were characterized by ${ }^{1} \mathrm{H}$ and ${ }^{13} \mathrm{C}$ NMR recorded on a Bruker AC $300 \mathrm{MHz}$ spectrometer. The chemical shifts were measured in ppm relative to $\mathrm{CD}_{2} \mathrm{Cl}_{2}$ as internal standard. NMR solvents $\left(\mathrm{CD}_{2} \mathrm{Cl}_{2}\right.$ and $\left.\mathrm{CD}_{3} \mathrm{OD}\right)$ were purchased from "Euriso-top" and used as received.

The water content of ionic liquids was determined by Karl Fischer coulometry using a "METROHM 756 KF" apparatus. Anolyte and catholyte were "coulomat AG" purchased from Hydranal.

The halide contents of ionic liquids were evaluated from the " $\mathrm{AgNO}_{3}$ test". This qualitative test is based on the formation of $\mathrm{AgCl}$ precipitate when an $\mathrm{AgNO}_{3}$ acid aqueous solution is contacted with a chloride source. In the case of hydrophobic ionic liquids, the test is operated during aqueous washing of the ionic liquid on a sample of the aqueous layer. For hydrophilic ionic liquids, the test was realized directly on a sample of the neat ionic liquid. This simple visual method permits the determination of chloride 
amount as low as $3 \cdot 10^{-3}$ mol.L $L^{-1}$. This has been demonstrated from independent results based on quantitative voltametric measurements of the halide oxidation wave.

The alkylimidazole or alkylpyrrolidine content of the ionic liquid was evaluated directly by acid-base titration into the halide precursor salts ([BMIm][Cl], [BuMePyrr $][\mathrm{Cl}]$, etc.) used for the synthesis [13]. The detection limit is of the order of 0.005 weight $\%$ and the residual content was found below 0.05 weight $\%$ for purified salts used in this study.

Some details of the ionic liquids syntheses are reported below:

- N-butyl-N-methylpyrrolidinium chloride [BuMePyrr][Cl]: An excess of freshly distilled 1-chlorobutane was added in one portion to 1-methylpyrrolidine in acetonitrile. The solution was stirred for $48 \mathrm{~h}$ at $90^{\circ} \mathrm{C}$. The solution was concentrated and ethyl acetate added. A precipitate formed. It was filtered, washed repeatedly with ethyl acetate. The product was then dried under vacuum. [BuMePyrr] [Cl] was obtained as a white hygroscopic solid (95\% yield). ${ }^{1} \mathrm{H}$ NMR $\left(\mathrm{CD}_{2} \mathrm{Cl}_{2}\right): \delta 0.93[\mathrm{t}$, $\mathrm{NCH}_{2} \mathrm{CH}_{2} \mathrm{CH}_{2} \mathrm{CH}_{3}$ ]; 1.37 [sext, $\mathrm{NCH}_{2} \mathrm{CH}_{2} \mathrm{CH}_{2} \mathrm{CH}_{3}$ ]; 1.66 [quint, $\mathrm{NCH}_{2} \mathrm{CH}_{2} \mathrm{CH}_{2} \mathrm{CH}_{3}$ ]; $2.19\left[\mathrm{~m}, \mathrm{NCH}_{2} \mathrm{CH}_{2} \mathrm{CH}_{2} \mathrm{CH}_{2} \mathrm{~N}\right.$ ]; $3.17\left[\mathrm{~s}, \mathrm{NCH}_{3}\right] ; 3.53\left[\mathrm{~m}, \mathrm{NCH}_{2} \mathrm{CH}_{2} \mathrm{CH}_{2} \mathrm{CH}_{3}\right] ; 3.70[\mathrm{~m}$, $\left.\mathrm{NCH}_{2} \mathrm{CH}_{2} \mathrm{CH}_{2} \mathrm{CH}_{2} \mathrm{~N}\right] ;{ }^{13} \mathrm{C} \mathrm{NMR}\left(\mathrm{CD}_{2} \mathrm{Cl}_{2}\right): \delta 13.83$ $\left[\mathrm{NCH}_{2} \mathrm{CH}_{2} \mathrm{CH}_{2} \mathrm{CH}_{3}\right] ; 20.19\left[\mathrm{NCH}_{2} \mathrm{CH}_{2} \mathrm{CH}_{2} \mathrm{CH}_{3}\right] ; 21.98$ $\left[\mathrm{NCH}_{2} \mathrm{CH}_{2} \mathrm{CH}_{2} \mathrm{CH}_{2} \mathrm{~N}\right] ; 26.24\left[\mathrm{NCH}_{2} \mathrm{CH}_{2} \mathrm{CH}_{2} \mathrm{CH}_{3}\right]$; $48.72\left[\mathrm{NCH}_{3}\right] ; 64.19\left[\mathrm{NCH}_{2} \mathrm{CH}_{2} \mathrm{CH}_{2} \mathrm{CH}_{3}\right] ; 64.60$ $\left[\mathrm{NCH}_{2} \mathrm{CH}_{2} \mathrm{CH}_{2} \mathrm{CH}_{2} \mathrm{~N}\right]$.

- 1-butyl-3-methylimidazolium bis(trifluoromethylsulfonyl)imide [BMIm] [NTf $\left.\mathbf{N}_{2}\right]$ : A solution of [BMIm] [Cl] in $\mathrm{CH}_{2} \mathrm{Cl}_{2}$ was added dropwise to a solution of lithium bis(trifluoromethylsulfonyl)imide. The solution was stirred at room temperature overnight. After concentration, the organic phase was washed several times with water until the " $\mathrm{AgNO}_{3}$ test" was negative. The $\mathrm{CH}_{2} \mathrm{Cl}_{2}$ was then evaporated and the ionic liquid dried under vacuum to afford $[\mathrm{BMIm}]\left[\mathrm{NTf}_{2}\right]$ as a colorless liquid (98\% yield). Water content: $19 \mathrm{ppm} .{ }^{1} \mathrm{H} \mathrm{NMR}\left(\mathrm{CD}_{2} \mathrm{Cl}_{2}\right): \delta 0.90[\mathrm{t}$, $\mathrm{NCH}_{2} \mathrm{CH}_{2} \mathrm{CH}_{2} \mathrm{CH}_{3}$ ]; 1.34 [sext, $\mathrm{NCH}_{2} \mathrm{CH}_{2} \mathrm{CH}_{2} \mathrm{CH}_{3}$ ]; 1.85 [quint, $\mathrm{NCH}_{2} \mathrm{CH}_{2} \mathrm{CH}_{2} \mathrm{CH}_{3}$ ]; 3.91 [s, $\mathrm{NCH}_{3}$ ]; 4.08 [t, $\left.\mathrm{NCH}_{2} \mathrm{CH}_{2} \mathrm{CH}_{2} \mathrm{CH}_{3}\right] ; 7.26[\mathrm{~s}, \mathrm{CH}] ; 7.32[\mathrm{~s}, \mathrm{CH}] ; 8.59$ $[\mathrm{CH}] .{ }^{13} \mathrm{C} \mathrm{NMR}\left(\mathrm{CD}_{2} \mathrm{Cl}_{2}\right): \delta 13.31\left[\mathrm{NCH}_{2} \mathrm{CH}_{2} \mathrm{CH}_{2} \mathrm{CH}_{3}\right]$; $19.64\left[\mathrm{NCH}_{2} \mathrm{CH}_{2} \mathrm{CH}_{2} \mathrm{CH}_{3}\right] ; 32.21\left[\mathrm{NCH}_{2} \mathrm{CH}_{2} \mathrm{CH}_{2} \mathrm{CH}_{3}\right]$; $36.58\left[\mathrm{NCH}_{3}\right] ; 50.28\left[\mathrm{NCH}_{2} \mathrm{CH}_{2} \mathrm{CH}_{2} \mathrm{CH}_{3}\right] ; 120.23[\mathrm{q}$, $\left.\left(\mathrm{CF}_{3} \mathrm{SO}_{2}\right)_{2} \mathrm{~N}\right] ; 122.77[\mathbf{C H}] ; 124.11[\mathbf{C H}] ; 136.07[\mathbf{C H}]$.

- N-butyl-N-methylpyrrolidinium bis(trifluoromethylsulfonyl)imide [BuMePyrr][ $\left.\mathbf{N T f}_{2}\right]$ : The procedure used for $[\mathrm{BMIm}]\left[\mathrm{NTf}_{2}\right]$ was applied starting from $\mathrm{LiNTf}_{2}$ and [BuMePyrr] [Cl]. [BuMePyrr] $\left[\mathrm{NTf}_{2}\right]$ was obtained as a colorless viscous liquid (91\% yield). Water content: $15 \mathrm{ppm}$. ${ }^{1} \mathrm{H}$ NMR $\left(\mathrm{CD}_{2} \mathrm{Cl}_{2}\right): \delta 0.98\left[\mathrm{t}, \mathrm{NCH}_{2} \mathrm{CH}_{2} \mathrm{CH}_{2} \mathrm{CH}_{3}\right] ; 1.40$ [sext, $\mathrm{NCH}_{2} \mathrm{CH}_{2} \mathrm{CH}_{2} \mathrm{CH}_{3}$ ]; 1.73 [quint, $\mathrm{NCH}_{2} \mathrm{CH}_{2} \mathrm{CH}_{2} \mathrm{CH}_{3}$ ]; $2.23\left[\mathrm{~m}, \mathrm{NCH}_{2} \mathrm{CH}_{2} \mathrm{CH}_{2} \mathrm{CH}_{2} \mathrm{~N}\right] ; 3.00\left[\mathrm{~s}, \mathrm{NCH}_{3}\right] ; 3.26[\mathrm{~m}$,
$\left.\mathrm{NCH}_{2} \mathrm{CH}_{2} \mathrm{CH}_{2} \mathrm{CH}_{3}\right] ; 3.47\left[\mathrm{~m}, \mathrm{NCH}_{2} \mathrm{CH}_{2} \mathrm{CH}_{2} \mathrm{CH}_{2} \mathrm{~N}\right] ;{ }^{13} \mathrm{C}$ NMR $\left(\mathrm{CD}_{2} \mathrm{Cl}_{2}\right): \delta 13.51\left[\mathrm{NCH}_{2} \mathrm{CH}_{2} \mathrm{CH}_{2} \mathrm{CH}_{3}\right] ; 19.91$ $\left[\mathrm{NCH}_{2} \mathrm{CH}_{2} \mathrm{CH}_{2} \mathrm{CH}_{3}\right] ; 21.90\left[\mathrm{NCH}_{2} \mathrm{CH}_{2} \mathrm{CH}_{2} \mathrm{CH}_{2} \mathrm{~N}\right]$; $26.04\left[\mathrm{NCH}_{2} \mathrm{CH}_{2} \mathrm{CH}_{2} \mathrm{CH}_{3}\right] ; 48.89\left[\mathrm{NCH}_{3}\right] ; 65.06$ $\left[\mathrm{NCH}_{2} \mathrm{CH}_{2} \mathrm{CH}_{2} \mathrm{CH}_{3}\right] ; 65.15\left[\mathrm{NCH}_{2} \mathrm{CH}_{2} \mathrm{CH}_{2} \mathrm{CH}_{2} \mathrm{~N}\right]$; $120.26\left[\mathrm{q},\left(\mathrm{CF}_{3} \mathrm{SO}_{2}\right)_{2} \mathrm{~N}\right]$.

- Triethylammonium bis(trifluoromethylsulfonyl)imide $\left[\mathbf{H N E t}_{\mathbf{3}}\right]\left[\mathbf{N T f}_{2}\right]$ : The procedure used for $[\mathrm{BMIm}]\left[\mathrm{NTf}_{2}\right]$ was applied starting from $\mathrm{LiNTf}_{2}$ and $\left[\mathrm{HNEt}_{3}\right][\mathrm{Cl}]$. $\left[\mathrm{HNEt}_{3}\right]\left[\mathrm{NTf}_{2}\right]$ was obtained as a colorless viscous liquid (87\% yield). Water content: $15 \mathrm{ppm} .{ }^{1} \mathrm{H} \mathrm{NMR}\left(\mathrm{CD}_{2} \mathrm{Cl}_{2}\right)$ :

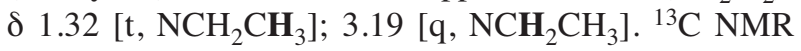
$\left(\mathrm{CD}_{2} \mathrm{Cl}_{2}\right): \delta 8.80\left[\mathrm{NCH}_{2} \mathrm{CH}_{3}\right] ; 47.76\left[\mathrm{NCH}_{2} \mathrm{CH}_{3}\right] ; 120.08$ $\left[\mathrm{q},\left(\mathrm{CF}_{3} \mathrm{SO}_{2}\right)_{2} \mathrm{~N}\right]$.

- 1-butyl-3-methylimidazolium tetrafluoroborate [BMIm] $\left[\mathbf{B F}_{4}\right]$ : A solution of $\mathrm{NaBF}_{4}$ and $[\mathrm{BMIm}][\mathrm{Cl}]$ was vigorously stirred at room temperature for 4 days in $\mathrm{CH}_{2} \mathrm{Cl}_{2}$. The reaction mixture was filtered and concentrated on a Rotavapor. The obtained viscous liquid was dissolved in water and extracted by $\mathrm{CH}_{2} \mathrm{Cl}_{2}$. The $\mathrm{CH}_{2} \mathrm{Cl}_{2}$ was then evaporated and $[\mathrm{BMIm}]\left[\mathrm{BF}_{4}\right]$ was obtained as a colorless viscous liquid (73\% yield). Water content: $231 \mathrm{ppm}$. ${ }^{1} \mathrm{H}$ NMR $\left(\mathrm{CD}_{2} \mathrm{Cl}_{2}\right): \delta 0.92\left[\mathrm{t}, \mathrm{NCH}_{2} \mathrm{CH}_{2} \mathrm{CH}_{2} \mathrm{CH}_{3}\right] ; 1.32$ [sext, $\mathrm{NCH}_{2} \mathrm{CH}_{2} \mathrm{CH}_{2} \mathrm{CH}_{3}$ ]; 1.84 [quint, $\mathrm{NCH}_{2} \mathrm{CH}_{2} \mathrm{CH}_{2} \mathrm{CH}_{3}$ ]; $3.91\left[\mathrm{~s}, \mathrm{NCH}_{3}\right] ; 4.16\left[\mathrm{t}, \mathrm{NCH}_{2} \mathrm{CH}_{2} \mathrm{CH}_{2} \mathrm{CH}_{3}\right] ; 7.36$ $[\mathrm{s}, \mathrm{CH}] ; 7.37[\mathrm{~s}, \mathrm{CH}] ; 8.69[\mathrm{CH}] .{ }^{13} \mathrm{C} \mathrm{NMR}\left(\mathrm{CD}_{2} \mathrm{Cl}_{2}\right): \delta$ $13.45\left[\mathrm{NCH}_{2} \mathrm{CH}_{2} \mathrm{CH}_{2} \mathrm{CH}_{3}\right] ; 19.69\left[\mathrm{NCH}_{2} \mathrm{CH}_{2} \mathrm{CH}_{2} \mathrm{CH}_{3}\right]$; $32.23\left[\mathrm{NCH}_{2} \mathrm{CH}_{2} \mathrm{CH}_{2} \mathrm{CH}_{3}\right] ; 36.53\left[\mathrm{NCH}_{3}\right] ; 50.16$ $\left[\mathrm{NCH}_{2} \mathrm{CH}_{2} \mathrm{CH}_{2} \mathrm{CH}_{3}\right] ; 122.67[\mathrm{CH}] ; 124.09[\mathrm{CH}] ; 136.53$ $[\mathrm{CH}]$.

- 1-butyl-3-methylimidazolium triflate [BMIm][OTf]: The procedure used for $[\mathrm{BMIm}]\left[\mathrm{BF}_{4}\right]$ was applied starting from $\mathrm{NH}_{4} \mathrm{OTf}$ and [BMIm][Cl]. [BMIm][OTf] was obtained as a colorless viscous liquid (86\% yield). Water content: $121 \mathrm{ppm} .{ }^{1} \mathrm{H}$ NMR $\left(\mathrm{CD}_{2} \mathrm{Cl}_{2}\right): \delta 0.96[\mathrm{t}$, $\mathrm{NCH}_{2} \mathrm{CH}_{2} \mathrm{CH}_{2} \mathrm{CH}_{3}$ ]; 1.37 [sext, $\mathrm{NCH}_{2} \mathrm{CH}_{2} \mathrm{CH}_{2} \mathrm{CH}_{3}$ ]; 1.87 [quint, $\mathrm{NCH}_{2} \mathrm{CH}_{2} \mathrm{CH}_{2} \mathrm{CH}_{3}$ ] $3.96\left[\mathrm{~s}, \mathrm{NCH}_{3}\right] ; 4.20$ [t, $\mathrm{NCH}_{2} \mathrm{CH}_{2} \mathrm{CH}_{2} \mathrm{CH}_{3}$ ]; 7.42 [s, $\mathrm{CH}$ ]; 7.43 [s, CH] ; 9.00 $[\mathrm{CH}] .{ }^{13} \mathrm{C}$ NMR $\left(\mathrm{CD}_{2} \mathrm{Cl}_{2}\right): \delta 13.42\left[\mathrm{NCH}_{2} \mathrm{CH}_{2} \mathrm{CH}_{2} \mathrm{CH}_{3}\right]$; $19.67\left[\mathrm{NCH}_{2} \mathrm{CH}_{2} \mathrm{CH}_{2} \mathrm{CH}_{3}\right] ; 32.25\left[\mathrm{NCH}_{2} \mathrm{CH}_{2} \mathrm{CH}_{2} \mathrm{CH}_{3}\right]$; $36.58\left[\mathrm{NCH}_{3}\right] ; 50.14\left[\mathrm{NCH}_{2} \mathrm{CH}_{2} \mathrm{CH}_{2} \mathrm{CH}_{3}\right] ; 121.21$ [q, $\left.\mathrm{CF}_{3} \mathrm{SO}_{3}\right] ; 122.71[\mathrm{CH}] ; 124.06[\mathrm{CH}] ; 136.87[\mathrm{CH}]$.

- 1-butyl-3-methylimidazolium hexafluorophosphate [BMIm] $\left[\mathbf{P F}_{6}\right]$ : A solution of $\mathrm{NaPF}_{6}$ and $[\mathrm{BMIm}][\mathrm{Cl}]$ was vigorously stirred at room temperature for 4 days in dichloromethane. The reaction mixture was filtered and concentrated on a Rotavapor. The obtained viscous liquid was dissolved in dichloromethane and $\mathrm{NaCl}$ was extracted by water. The $\mathrm{CH}_{2} \mathrm{Cl}_{2}$ was then evaporated. [BMIm] $\left[\mathrm{PF}_{6}\right]$ was obtained as a colorless viscous liquid (80\% yield). Water content: 29 ppm. ${ }^{1} \mathrm{H}$ NMR $\left(\mathrm{CD}_{2} \mathrm{Cl}_{2}\right): \delta 0.93[\mathrm{t}$, $\mathrm{NCH}_{2} \mathrm{CH}_{2} \mathrm{CH}_{2} \mathrm{CH}_{3}$ ]; 1.35 [sext, $\mathrm{NCH}_{2} \mathrm{CH}_{2} \mathrm{CH}_{2} \mathrm{CH}_{3}$ ]; 1.84 [quint, $\mathrm{NCH}_{2} \mathrm{CH}_{2} \mathrm{CH}_{2} \mathrm{CH}_{3}$ ]; $3.88\left[\mathrm{~s}, \mathrm{NCH}_{3}\right.$ ]; 4.13 [t, 
$\left.\mathrm{NCH}_{2} \mathrm{CH}_{2} \mathrm{CH}_{2} \mathrm{CH}_{3}\right] ; 7.31[2 \mathrm{~s}, \mathrm{CH}] ; 8.41[\mathrm{CH}] .{ }^{13} \mathrm{C} \mathrm{NMR}$ $\left(\mathrm{CD}_{2} \mathrm{Cl}_{2}\right): \delta 13.42\left[\mathrm{NCH}_{2} \mathrm{CH}_{2} \mathrm{CH}_{2} \mathrm{CH}_{3}\right] ; 19.69$ $\left[\mathrm{NCH}_{2} \mathrm{CH}_{2} \mathrm{CH}_{2} \mathrm{CH}_{3}\right] ; 32.14\left[\mathrm{NCH}_{2} \mathrm{CH}_{2} \mathrm{CH}_{2} \mathrm{CH}_{3}\right] ; 36.59$ $\left[\mathrm{NCH}_{3}\right] ; 50.30\left[\mathrm{NCH}_{2} \mathrm{CH}_{2} \mathrm{CH}_{2} \mathrm{CH}_{3}\right] ; 122.69[\mathrm{CH}]$; $124.07[\mathrm{CH}] ; 135.99[\mathrm{CH}]$

- 1-butyl-3-methylimidazolium hexafluoro-antimonate $[\mathbf{B M I m}]\left[\mathbf{S b F}_{6}\right]:$ The procedure used for $[\mathrm{BMIm}]\left[\mathrm{PF}_{6}\right]$ was applied starting from $\mathrm{NaSbF}_{6}$ and $[\mathrm{BMIm}][\mathrm{Cl}]$. $[\mathrm{BMIm}]\left[\mathrm{SbF}_{6}\right]$ was obtained as a colorless viscous liquid (43\% yield). Water content: $15 \mathrm{ppm} .{ }^{1} \mathrm{H}$ NMR $\left(\mathrm{CD}_{2} \mathrm{Cl}_{2}\right)$ : $\delta 0.90\left[\mathrm{t}, \mathrm{NCH}_{2} \mathrm{CH}_{2} \mathrm{CH}_{2} \mathrm{CH}_{3}\right.$ ]; 1.30 [sext, $\mathrm{NCH}_{2} \mathrm{CH}_{2} \mathrm{CH}_{2} \mathrm{CH}_{3}$; 1.80 [quint, $\mathrm{NCH}_{2} \mathrm{CH}_{2} \mathrm{CH}_{2} \mathrm{CH}_{3}$ ]; 3.95 [s, $\mathrm{NCH}_{3}$ ]; 4.10 [t, $\left.\mathrm{NCH}_{2} \mathrm{CH}_{2} \mathrm{CH}_{2} \mathrm{CH}_{3}\right] ; 7.30$ [s, $\mathrm{CH}$ ]; $7.31[\mathrm{~s}, \mathrm{CH}] ; 8.30$ $[\mathrm{CH}] .{ }^{13} \mathrm{C}$ NMR $\left(\mathrm{CD}_{2} \mathrm{Cl}_{2}\right): \delta 13.2\left[\mathrm{NCH}_{2} \mathrm{CH}_{2} \mathrm{CH}_{2} \mathrm{CH}_{3}\right]$; $19.5\left[\mathrm{NCH}_{2} \mathrm{CH}_{2} \mathrm{CH}_{2} \mathrm{CH}_{3}\right] ; 31.9\left[\mathrm{NCH}_{2} \mathrm{CH}_{2} \mathrm{CH}_{2} \mathrm{CH}_{3}\right]$; $36.40\left[\mathrm{NCH}_{3}\right] ; 50.20\left[\mathrm{NCH}_{2} \mathrm{CH}_{2} \mathrm{CH}_{2} \mathrm{CH}_{3}\right] ; 122.60[\mathrm{CH}]$; $123.90[\mathrm{CH}] ; 135.4[\mathrm{CH}]$.

- 1-methyl-3-(2-sulfonate)ethylimidazolium [MeIm( $\left.\left(\mathrm{CH}_{2}\right)_{4} \mathbf{S O}_{3}\right]$ : A freshly distilled 1-methylimidazole was added dropwise to 1 equivalent of butanesultone in dry toluene. The solution was stirred for $1 \mathrm{~h}$ at room temperature and refluxed for $12 \mathrm{~h}$. A precipitate formed. It was filtered, washed repeatedly with toluene and $\mathrm{Et}_{2} \mathrm{O}$. The product was then dried under vacuum at $40^{\circ} \mathrm{C}$. The zwitterion $\left[\mathrm{MeIm}\left(\mathrm{CH}_{2}\right)_{4} \mathrm{SO}_{3}\right]$ was obtained as a white solid (>90\% yield). ${ }^{1} \mathrm{H}$ NMR $\left(\mathrm{CD}_{3} \mathrm{OD}\right): \delta 1.72$ [quint, $\mathrm{NCH}_{2} \mathrm{CH}_{2} \mathrm{CH}_{2} \mathrm{CH}_{2} \mathrm{SO}_{3}$ ]; 1.99 [quint, $\mathrm{NCH}_{2} \mathrm{CH}_{2} \mathrm{CH}_{2} \mathrm{CH}_{2} \mathrm{SO}_{3}$ ]; $2.78\left[\mathrm{t}, \mathrm{NCH}_{2} \mathrm{CH}_{2} \mathrm{CH}_{2} \mathrm{CH}_{2} \mathrm{SO}_{3}\right] ; 3.78\left[\mathrm{~s}, \mathrm{NCH}_{3}\right] ; 4.19[\mathrm{t}$, $\left.\mathrm{NCH}_{2} \mathrm{CH}_{2} \mathrm{CH}_{2} \mathrm{CH}_{2} \mathrm{SO}_{3}\right] ; 7.51[\mathrm{~s}, \mathrm{CH}] ; 7.59[\mathrm{~s}, \mathbf{C} \underline{\mathbf{H}}] ; 8.89$ $[\mathrm{s}, \mathrm{C} \underline{\mathbf{H}}]$.

- 1-methyl-3-(2-sulfonic acid)ethylimidazolium triflate $\left[\mathrm{MeIm}\left(\mathrm{CH}_{2}\right)_{4} \mathrm{SO}_{3} \mathbf{H}\right]\left[\mathrm{CF}_{3} \mathrm{SO}_{3}\right]$ : Dropwise addition of $1 \mathrm{eq}$ of HOTf to $\left[\mathrm{MeIm}\left(\mathrm{CH}_{2}\right)_{4} \mathrm{SO}_{3}\right]$ in dry toluene yields to the formation of an oily product which was repeatedly washed with toluene and finally dried under vacuum ( $96 \%$ yield). ${ }^{1} \mathrm{H} \mathrm{NMR}\left(\mathrm{CD}_{3} \mathrm{OD}\right): \delta 1.79$ [quint, $\mathrm{NCH}_{2} \mathrm{CH}_{2} \mathrm{CH}_{2} \mathrm{CH}_{2} \mathrm{SO}_{3}$ ]; 2.04 [quint, $\mathrm{NCH}_{2} \mathrm{CH}_{2} \mathrm{CH}_{2} \mathrm{CH}_{2} \mathrm{SO}_{3}$ ]; 2.87 [t, $\left.\mathrm{NCH}_{2} \mathrm{CH}_{2} \mathrm{CH}_{2} \mathrm{CH}_{2} \mathrm{SO}_{3}\right] ; 3.92\left[\mathrm{~s}, \mathrm{NCH}_{3}\right] ; 4.26[\mathrm{t}$, $\left.\mathrm{NCH}_{2} \mathrm{CH}_{2} \mathrm{CH}_{2} \mathrm{CH}_{2} \mathrm{SO}_{3}\right] ; 7.56$ [s, CH]; $7.64[\mathrm{~s}, \mathrm{CH}] ; 8.93$ $[\mathrm{CH}] .{ }^{13} \mathrm{C}$ NMR $\left(\mathrm{CD}_{3} \mathrm{OD}\right): \delta 22.68\left[\mathrm{NCH}_{2} \mathrm{CH}_{2} \mathrm{CH}_{2} \mathrm{CH}_{2} \mathrm{SO}_{3}\right]$; $29.84\left[\mathrm{NCH}_{2} \mathrm{CH}_{2} \mathrm{CH}_{2} \mathrm{CH}_{2} \mathrm{SO}_{3}\right] ; 36.51\left[\mathrm{NCH}_{3}\right] ; 50.31$ $\left[\mathrm{NCH}_{2} \mathrm{CH}_{2} \mathrm{CH}_{2} \mathrm{CH}_{2} \mathrm{SO}_{3}\right] ; 51.49\left[\mathrm{NCH}_{2} \mathrm{CH}_{2} \mathrm{CH}_{2} \mathrm{CH}_{2} \mathrm{SO}_{3}\right]$; $123.71[\mathbf{C H}] ; 125.03[\mathrm{CH}] ; 138.21[\mathrm{CH}] ; 122.1[\mathrm{q}$, $\mathrm{CF}_{3} \mathrm{SO}_{3}$ ]

\subsection{Isobutene Dimerization Experiments}

The catalytic system was first prepared in a Schlenk under argon atmosphere by adding controlled amount of Brønsted acid in $4 \mathrm{~mL}$ of ionic liquid. This mixture was stirred at room temperature until the acid was completely dissolved in the ionic liquid. All the dimerization experiments were carried out in a $150 \mathrm{~mL}$ glassware pressure reaction vessel immerged in a temperature controlled bath. In all experiments, the rate of agitation was constant and ensured by a magnetic stirring bar. In a typical experiments, the catalytic system was first introduced in the reactor at room temperature. Then, a defined amount $(20 \mathrm{~mL})$ of isobutene (with $5 \%$ of butane as internal standard) was charged in the reactor. After stabilization of the reactor at a given temperature, agitation was started. During all the experiment, temperature and pressure of the system were followed. After a given reaction time, all the hydrocarbon upper phase was withdrawn and the lower phase containing catalyst can be reused. Organic samples of reaction mixture were washed with diluted $\mathrm{NaOH}$ aqueous solution and then analyzed by gas chromatography using heptane as external standard (FID detector, PONA, $50 \mathrm{~m}$ capillary column). Temperature programming: $10 \mathrm{~min}$ at $35^{\circ} \mathrm{C}$ then $5^{\circ} \mathrm{C} / \mathrm{min}$ up to $70^{\circ} \mathrm{C} ; 10 \mathrm{~min}$ at $70^{\circ} \mathrm{C}$ then $10^{\circ} \mathrm{C} / \mathrm{min}$ up to $270^{\circ} \mathrm{C}$ for $20 \mathrm{~min}$. Isobutene conversion is expressed in weight percent as the mass of products formed with respect to the mass of isobutene. Dimer selectivity is expressed in weight percent from the mass of dimers and the mass of total products formed. The accuracy of the dimerization has been evaluated by reproducing 3 times a standart catalytic test (entry 2, Tab. 1).

\section{CONCLUSION}

In this paper, we discussed about the possible Brønsted acidity-activity relationship in ionic liquids applied to the selective dimerization of isobutene. The acidity level, through the determination of the apparent Hammett function, was first evaluated for ionic liquids to which strong acids have been added. It was found, for the investigated ionic liquids, that the nature of the cation does not play a dominant role, whereas changing the nature of the anion of the ionic liquid may lead to very different acidities. These results show that the relationship activityacidity is not straightforward: for all ionic liquids except BMINTF $_{2}$, the acidities are in good agreement with the catalytic results obtained for the selective dimerization of isobutene. $\mathrm{BMINTF}_{2}$ gave unexpectedly good catalytic results despite a lower acidity. We have then proposed that the catalytic activity and selectivity performance depend on both the solvated proton content (relative activity) and the coordinating strength of the IL anion (intrinsic activity of the proton). With a right choice of the ionic liquid anion as well as the acid and its concentration, very good performances were obtained. For instance, the best case we have found in terms of selectivity and reaction rate is represented by the [BMIm][OTf] solvent to which a large amount of $\left[\mathrm{MeIm}\left(\mathrm{CH}_{2}\right)_{4} \mathrm{SO}_{3} \mathrm{H}\right][\mathrm{OTf}]$ has been added. It was possible to recycle this catalytic system without loss of activity and selectivity. 


\section{REFERENCES}

1 Parvulescu V.I., Hardacre C. (2007) Chem. Rev. 107, 2615.

2 Giernoth R. (2007) Top. Curr. Chem. 276, 1.

3 Wasserscheid P., Welton T. (2008) Ionic Liquids in Synthesis, Wasserscheid P., Welton T. (eds), Wiley-VCH, Weinheim.

4 Olivier-Bourbigou H. (2005) Catalysis in non aqueous ionic liquids, in Multiphase Homogeneous Catalysis, Cornils B., Herrmann W.A., Horvath I.T., Leitner W., Mecking S., OlivierBourbigou H., Vogt D. (eds), Wiley-VCH, Weinheim.

5 Olivier-Bourbigou H. (2005) Acidic Catalysis, in Multiphase Homogeneous Catalysis, Cornils B., Herrmann W.A., Horvath T.T., Leitner W., Mecking S., Olivier-Bourbigou H., Vogt D. (eds), Wiley-VCH, Weinheim.

6 Johnson K.E., Pagni R.M., Bartmess J. (2007) Monatsh. Chem. 138, 1077.

7 Greaves T.L., Drummond C.J. (2008) Chem. Rev. 108, 206.

8 Mc Farlane D.R., Pringle J.M., Johansson K.M., Forsyth S.A., Forsyth M. (2006) Chem. Commun., 1905.

9 Welton T. (1999) Chem. Rev. 99, 2071.

10 Olivier-Bourbigou H., Commereuc D., Martin O., Magna L., Pellier E. (2003) US Patent US 2003/0060359 A1.

11 Thomazeau C., Olivier-Bourbigou H., Magna L., Luts S., Gilbert B. (2003) J. Am. Chem. Soc. 125, 5264.

12 Robert T., Olivier-Bourbigou H., Magna L., Gilbert B. (2007) ECS Trans. 3, 35, 71 .

13 Robert T., Magna L., Olivier-Bourbigou H., Gilbert B. (2008) publication in progress.

14 Mc Farlane D.R., Seddon K.R. (2007) Aust. J. Chem. 60, 3.

15 Duan Z., Gu Y., Zhang J., Zhu L., Deng Y. (2006) J. Mol. Catal. A: Chem. 250, 163 .

16 Cole A.C., Jensen J.L., Ntai I., Tran K.L., Weaver K.J., Forbes D.C., Davis J.H. Jr. (2002) J. Am. Chem. Soc. 124, 5962.

17 Davis J.H. (2007) US Patent, US 7,208,605 B2.

18 Xing H., Wang T., Zhou Z., Dai Y. (2007) J. Mol. Catal. A: Chem. 264, 1-2, 53 .

19 Liu X., Zhou J., Guo X., Liu M., Ma X., Song C., Wang C. (2008) Ind. Eng. Chem. Res. 47, 5298.
20 Kolah A.K., Zhiwen Q., Mahajani S.M. (2001) Chem. Innovation 31, 3, 15.

21 Di Girolamo M., Lami M., Marchionna M., Pescarollo E., Tagliabue L., Ancillotti F. (1997) Ind. Eng. Chem. Res. 36, 11, 4452 .

22 Burnes E., Wichelns D. (2005) Energ. Policy 33, 1155.

23 Tremillon B. (1974) Chemistry in Non-Aqueous Solvents, Reidel D. (ed.), Dordrecht.

24 Fraser K.J., Izgorodina E.I., Forsyth M., Scott J.L., Mc Farlane D.R. (2007) Chem. Commun., 3817.

25 Johansson K.M., Izgorodina E.I., Forsyth M., Mc Farlane D.R., Seddon K.R. (2008) Phys. Chem. Chem. Phys. 10, 2972.

26 D’Anna F., Noto R. (2007) Tetrahedron 63, 11681.

27 Fry A.J. (2003) J. Electroanal. Chem. 546, 35.

28 Tokuda H., Tsuzuki S., Susan M.A.B.H., Hayamizu K., Watanabe M. (2006) J. Phys. Chem. B 110, 19593.

29 Bruckenstein S. (1960) J. Am. Chem. Soc. 82, 307.

30 Tremillon B. (1993) Electrochimie analytique et réactions en solution, Masson ed., Paris.

31 Popovych O., Tomkins R.P.T. (1981) NonAqueous Solution in Chemistry, Springer, J. Wiley \& Sons ed., Berlin.

32 Weissermel K., Arpe H.-J. (2003) Industrial Organic Chemistry, Wiley-VCH, Weinheim.

33 Malherbe C., Robert T., Magna L., Olivier-Bourbigou H., Gilbert B. (2009) ECS Trans. (in press).

34 Marchionna M., Di Girolamo M., Patrini R. (2001) Catal. Today 65, 2-4, 397.

35 Honkela M.L., Krause A.O.I. (2003) Catal. Lett. 87, 3-4, 113.

36 Gu Y., Shi F., Deng Y. (2003) Catal. Commun. 4, 597.

37 Bonhôte P., Papageorgiou A.P., Kalyanasundaram N., Grätzel M. (1996) Inorg. Chem. 35, 1168.

38 Suarez P.A.Z., Dullius J.E.L., Einloft S., de Souza R.F., Dupont J. (1996) Polyhedron 15, 1217.

39 Gallo V., Mastrorilli P., Nobile C.F., Romanazzi G., Suranna G.P. (2002) Dalton Trans. 23, 4339.

Final manuscript received in April 2009 Published online in October 2009 or distributed for profit or commercial advantage and that copies bear this notice and the full citation on the first page. Copyrights for components of this work owned by others than IFP must be honored. Abstracting with credit is permitted. To copy otherwise, to republish, to post on servers, or to redistribute to lists, requires prior specific permission and/or a fee: Request permission from Documentation, Institut français du pétrole, fax. +33147527078 , or revueogst@ifp.fr. 